\section{UCDNN}

LIBRARY
University of Connecticut OpenCommons@UConn

$1-2010$

\title{
Optimal Use of Blood in Trauma Patients
}

Philip C. Spinella

University of Connecticut School of Medicine and Dentistry

Follow this and additional works at: https://opencommons.uconn.edu/pcare_articles

Part of the Medicine and Health Sciences Commons

\section{Recommended Citation}

Spinella, Philip C., "Optimal Use of Blood in Trauma Patients" (2010). Articles - Patient Care. 27.

https://opencommons.uconn.edu/pcare_articles/27 
Published in final edited form as:

Biologicals. 2010 January ; 38(1): 72-77. doi:10.1016/j.biologicals.2009.10.007.

\title{
Optimal use of blood in trauma patients
}

\author{
John B. Holcomb ${ }^{a,}{ }^{*}$ and Philip C. Spinellab,c \\ ${ }^{a}$ Division of Acute Care Surgery, Center for Translational Injury Research, University of Texas \\ Health Science Center, 6410 Fannin St., Suite 1100 Houston, TX 77030, USA \\ ${ }^{b}$ Department of Pediatrics, University of Connecticut, Pediatric Intensivist, Stamford, CT, USA \\ 'Department of Surgery, Connecticut Children's Medical Center, Hartford, CT, USA
}

\section{Abstract}

Injury is rapidly becoming the leading cause of death worldwide, and uncontrolled hemorrhage is the leading cause of potentially preventable death. In addition to crystalloid and/or colloid based resuscitation, severely injured trauma patients are routinely transfused RBCs, plasma, platelets, and in some centers either cryoprecipitate or fibrinogen concentrates or whole blood. Optimal timing and quantity of these products in the treatment of hypothermic, coagulopathic and acidotic trauma patients is unclear. The immediate availability of these components is important, as most hemorrhagic deaths occur within the first 3-6 h of patient arrival. While there are strongly held opinions and longstanding traditions in their use, there are little data within which to logically guide resuscitation therapy. Many current recommendations are based on euvolemic elective surgery patients and incorporate laboratory data parameters not widely available in the first few minutes after patient arrival. Finally, blood components themselves have evolved over the last 30 years, with great attention paid to product safety and inventory management, yet there are surprisingly limited clinical outcome data describing the long term effects of these changes, or how the components have improved clinical outcomes compared to whole blood therapy. When focused on survival of the rapidly bleeding trauma patient, it is unclear if current component therapy is equivalent to whole blood transfusion. In fact data from the current war in Iraq and Afghanistan suggest otherwise. All of these factors have contributed to the current situation, whereby blood component therapy is highly variable and not driven by long term patient outcomes. This review will address the issues raised above and describe recent trauma patient outcome data utilizing predetermined plasma:platelet:RBC transfusion ratios and an ongoing prospective observational trauma transfusion study.

\section{Keywords}

Hemorrhage; Transfusion; Coagulopathy; Shock; Trauma

\section{Introduction}

Injury is a major public health problem. Around the world, injury is responsible for more than 5 million deaths per year, while in the United States, injury accounts for over 150,000 deaths and over 3 million non-fatal injuries per year [1]. In the United Sates, traumatic injury is the leading cause of death for patients between the ages of 1 and 40 [2]. Across the globe, injury is a leading cause of death and disability in adults worldwide [3]. Rural civilian

(C) 2009 The International Association for Biologicals. Published by Elsevier Ltd. All rights reserved.

*Corresponding author. Tel.: 1713500 5493. John.Holcomb@uth.tmc.edu (J.B. Holcomb).. 
data indicates that approximately $10 \%$ of traumatic deaths are preventable [4,5], and $16 \%$ of preventable deaths are due to hemorrhage [6]. Hemorrhagic deaths typically occur very early, usually within the first 6 hof admission [7-15]. While these statistics are sobering, it must be remembered that the vast majority of trauma patients are not at risk for a transfusion and have little risk of dying. Only $25 \%$ of patients admitted to busy trauma centers receive a unit of RBCs and of those only $25 \%$ are massively transfused. This represents approximately $2-3 \%$ of all civilian trauma admissions [16-18]. The $25 \%$ of patients presenting with severe traumatic injury and who are in shock are usually coagulopathic in the Emergency Department [19-23]. Shock and coagulopathy upon admission have both been associated with massive transfusion and increased mortality [22,23]. These patients are critically ill, are at risk of immediate hemorrhagic mortality, and constitute the largest group of potentially preventable deaths. Early identification of coagulopathy and shock coupled with predefined resuscitation strategies aimed at reversing the coagulopathy of trauma, controlling bleeding and improving survival in this group of severely injured patients is imperative [24-27].

\section{Discussion}

\subsection{History}

Over the last 40 years transfusion in the developed world has evolved from use of predominately whole blood to largely component therapy. In the developed world, very little whole blood is used, while in the developing countries, and in many military situations, its use is not uncommon [28]. After the development of whole blood fractionation in the 1940s, component therapy now predominates as the primary transfusion approach, primarily due to concerns for resource utilization and safety [29-32]. This change occurred without strong evidence documenting at least equivalent clinical outcomes between whole blood and component therapy in massively transfused patients [33]. In addition, regulatory approval of $\mathrm{RBC}$ storage solutions are based upon a $24 \mathrm{~h} \mathrm{RBC}$ membrane viability and ATP concentrations instead of the ability of RBCs to deliver oxygen to the microvasculature, adverse effects on inflammation or immune function with stored RBCs, or most importantly improved patient outcomes [31]. We are unaware of any Level 1 or 2 data, focused on patient outcomes, which compare component therapy with whole blood in rapidly bleeding trauma patients. Current published transfusion guidelines regarding indications for blood components were based upon expert opinion, experiments in euvolemic patients requiring elective surgery and data from the modified whole blood era which is no longer commonly available[33,34]. While component therapy does convey a logistical and inventory management benefit, it is extremely uncertain if the current reliance on component therapy is clinically superior to whole blood, especially in the massively transfused patients. Recent retrospective data from the ongoing conflict suggests that whole blood is superior to component therapy in the massively transfused trauma patient [35-41].

\subsection{Damage control resuscitation}

Prompted by new data from combat casualties, an evolution of opinion is occurring in the trauma and transfusion medicine communities regarding the optimal resuscitative approach to hemorrhagic shock [42-49]. Damage control resuscitation (DCR) is the overall guiding concept to emerge from the recent military experience [47]. DCR includes permissive hypotension as first described by Cannon in 1918 and Beecher in 1945 and can be summarized as allowing the blood pressure to remain at lower than normal to promote thrombus formation while still providing enough perfusion to end organs $[42,43]$. In other words, the goal of permissive hypotension is to prevent increasing the blood pressure to a threshold where a forming thrombus will not be able to achieve hemostasis, and rebleeding occurs. This has been called "popping the clot" and is typically seen when systolic blood 
pressures rise $>90 \mathrm{~mm} \mathrm{Hg} \mathrm{[50].} \mathrm{This} \mathrm{concept} \mathrm{is} \mathrm{practiced} \mathrm{prior} \mathrm{to} \mathrm{surgical} \mathrm{control,} \mathrm{after}$ which full resuscitation to normal values occurs. The practice and literature supporting permissive hypotension has been well documented and will not be discussed further [51].

Damage control resuscitation and hemostatic resuscitation are concepts that have been recently developed and are being widely implemented as the optimal resuscitative and transfusion approach to patients with hemorrhagic shock and immediately life-threatening injuries. Similar to damage control surgery the goal of damage control resuscitation is to "stay out of trouble instead of getting out of trouble". Therefore in patients with severe traumatic injury the goal is to minimize iatrogenic resuscitation injury, prevent worsening of the presenting traumatic shock and coagulopathy, and to obtain definitive hemostasis. Once this is achieved the next immediate goal is to rapidly reverse shock, hypocoagulation, intravascular volume depletion, and maintain appropriate oxygen delivery and cardiac output. Fortunately, these measures are required infrequently as massive transfusion patients comprise only $3-8 \%$ of civilian and military trauma admissions, respectively.

DCR also advocates for the rapid control of surgical bleeding, prevention of acidosis, hypocalcemia and hypothermia, and the limitation of excessive crystalloid use to decrease hemodilution. All of these principles are intended to prevent inducing or exacerbating a hypocoagulable state in these patients with severe traumatic injury who are at high risk of developing or worsening severe shock and coagulopathy. Hemostatic resuscitation is a component of DCR and is a term to describe a unified transfusion approach to severe hemorrhagic shock. Hemostatic resuscitation advocates for the transfusion of RBCs, plasma, and platelets in a 1:1:1 ratio and the use of thawed plasma to achieve this ratio upon admission. This approach is also intended to minimize exacerbating a dilutional coagulopathy by replacing lost blood with plasma and platelet containing products instead of early and large amounts of crystalloids and RBCs. This approach has been widely studied, and is quickly becoming a common resuscitation approach in severely injured patients [52-65]. Lastly in the austere civilian or military situation, the use of fresh whole blood is recommended for those patients who have massive hemorrhage.

These suggested changes at first glance appear radical. However upon inspection of the literature supporting current practices, one finds generally underwhelming data. Current ATLS recommendations are based on a single paper from 1985, without a control group and comprising only 18 patients [66]. The influential paper by Counts et al. published in 1979 and totaling 29 patients, admonished the use of plasma as a resuscitation product, yet utilized whole blood transfusion, not the RBCs we use today [67]. Unfortunately the admonishment against FFP transfusion is what is remembered, not what blood product was transfused. Finally, the seminal work of Carrico and Shires recommended minimal crystalloid (by today's standards) while readying the whole blood transfusions for the seriously injured patient in shock [68]. If one were to translate their work to today, their recommendations are very similar to those of damage control resuscitation.

While most of the literature reviewed is in patients with traumatic injury, there are already compelling data from massively bleeding from ruptured aortic aneurysms patients, postoperative neonatal cardiac surgery and obstetric hemorrhage using the DCR concepts [69-71]. As this literature develop over the next few years, it will be interesting to observe if patients suffering massive hemorrhage from a variety of different etiologies benefit from the DCR approach to intravascular hemostasis.

Patients who develop traumatic coagulopathy often require a Massive Transfusion (MT) conventionally defined as 10 or more units of RBCs within the first $24 \mathrm{~h}$ of admission in adults. Cotton et al. has evaluated the DCR approach by implementing a multi-disciplinary 
massive transfusion guideline and a comprehensive performance improvement assessment. With a before and after design, they documented an association with increased survival with earlier application of a predefined MT guideline [61]. The later group had a lower multiorgan failure (MOF) rate 20 vs $9 \%, p<0.01$, and a higher 30 day survival higher 38 vs $57 \%$, $p<0.01$. The differences were attributed to rapid and earlier transfusion of increased plasma and platelets ratios

\subsection{Traumatic coagulopathy and acute coagulopathy of trauma-shock}

Traumatic coagulopathy is a hypocoagulable state that occurs in the most severely injured. Once thought to develop over time and with dilution, it is now understood to be present on admission to the emergency department and coexisting with shock. This process has been termed the acute coagulopathy of trauma-shock (ACoTS)[19,20]. Mathematical models have determined that hemodilution occurs after patients are given excessive crystalloids and red blood cells (RBCs) worsening shock induced hypocoagulation [33]. The development of hypothermia, hypocalcemia and acidosis each can further contribute to worsening of this initial coagulopathic state. The degree of hypocoagulation upon admission has been determined to be independently associated with massive transfusion and mortality in trauma patient [21,22]. Since death from hemorrhage occurs quickly, usually within 3-6 h from injury, the rapid identification of acidemia as an indicator of shock and coagulopathy is essential, as we think early and aggressive treatment with blood products may reverse these conditions and improve survival. This is the central tenant of DCR and recent military and civilian retrospective studies support this concept.

\subsection{Avoidance of hemodilution}

The current standard approach taught in the Advanced Trauma Life Support (ATLS) course for adults with significant bleeding is to initially administer 1-2 1 of isotonic crystalloids and then to transfuse RBCs until coagulopathy is recognized by laboratory analysis at which point plasma should be transfused. In addition, practice guidelines for blood component therapy by the American Society of Anesthesiologists Task Force on Blood Component Therapy suggest that platelet transfusion is indicated for surgical patients with microvascular bleeding only when the serum platelet concentration is less than 50,000-100,000 [34]. This approach is based on expert opinion and likely is appropriate for the roughly $92-97 \%$ of trauma patients who are not significantly hypovolemic, in shock and who do not require a massive transfusion. For the 3-8\% of trauma patients who require a massive transfusion this approach frequently results in liters of transfused $\mathrm{RBC}$ and crystalloid transfusion prior to their first dose of plasma or platelets, likely exacerbating their already present coagulopathy and increasing their risk of death from hemorrhage. Adverse clinical outcomes associated with over-resuscitating critically ill patients with crystalloids was described by FD Moore and Shires G in 1968 [72], reiterated in a recent review by Cotton [73], and confirmed in prospective cohort studies [74] and randomized controlled trials [75,76]. In addition to the hemodiluting effects of excessive crystalloids for patients at high risk of coagulopathy, the proinflammatory nature of crystalloids is under-appreciated and also well described in Cotton's review. Preliminary data from our laboratory suggests that freshly thawed plasma is less inflammatory than Lactated Ringers, when measured on endothelial cells made permeable by hypoxia [77]. Interestingly, thawed and then stored (5 days) plasma exacerbates the permeability of these cells. Furthermore, aged thawed plasma may result in decreased survival compared to freshly thawed plasma in a hemorrhagic shock rat model. We hypothesize that freshly thawed plasma, when used as a resuscitation fluid may minimize endothelial damage associated with shock and serve to repair the large endothelial surface. The same concerns exist for the over-use of RBCs in the initial phase of the resuscitation of a patient in hemorrhagic shock. When large amounts of RBCs are initially transfused this further hemodilutes the patient, secondary to plasma protein dilution, and 
may also contribute to exacerbating a hyper-inflammatory and immune deficient state, especially when older RBCs are transfused. To minimize the development of a dilutional coagulopathy, DCR principles advocate for the minimal use of crystalloids and the use of fresh plasma, RBCs, and platelets in a 1:1:1 ratio for patients at high risk of death secondary to hemorrhage from traumatic injuries.

\subsection{Plasma, $R B C s$, platelets in a 1:1:1 ratio}

Until very recently there has been very little literature to guide the use of blood components in the resuscitation of patients with hemorrhagic shock. In fact the only randomized controlled trial examining the efficacy of platelets compared to plasma was performed by Reed et al. in 33 patients with massive transfusion [78]. This small study used modified whole blood, and so one must be careful translating their results directly to transfusion therapy today. Since fresh or even whole blood is no longer available at most western institutions, practitioners have had to adjust to the availability of components only and transfuse plasma, RBCs, and platelets in a 1:1:1 ratio (reconstituted whole blood). Component therapy was substituted for whole blood in the US in the late 1970s and early 1980s. In the years after the transition from whole blood to components, several studies suggested that increased plasma and platelets were required for patients with severe traumatic injury and hemorrhage [62,63,79]. Unfortunately, these studies were not recognized for the important message they conveyed.

Currently there are 25 large adult US Military and civilian retrospective studies, both single and multicenter and in penetrating and blunt injury populations, the majority of which indicate in massive transfusion patients, when groups of equal injury severity are compared, a high ratio of plasma and platelets to RBCs, (approximating a median 1:1:1 unit ratio) is associated with improved survival [24-26,48,52-65]. Since the majority of these reports are retrospective and subject to bias, particularly survivorship bias, they must be interpreted with caution. Survivorship bias in this situation means that plasma and platelets were available only for those patients that were bleeding slowly enough to receive them, and that rapidly bleeding patients died before receiving products. It is important to note though that many of these studies have excluded patients who died within the first 30-60 min or in the emergency department, specifically to minimize this concern. This exclusion period should have removed those patients who were bleeding to death within the time when plasma and platelets were unavailable. These retrospective studies cannot account for "ordering bias" or the lack of physicians rapidly requesting these products from the blood bank. Even with excluding these patients, an association between increased ratios of plasma and platelets to RBCs with increased survival still remained. It is unclear if the increased death in patients receiving low plasma and platelet to $\mathrm{RBC}$ ratios is due to a delay in ordering the products or a true survival bias in these retrospective studies. Snyder et al. have explored this issue and in a small single center study concluded that after adjustment for survival bias a high ratio of plasma:RBCs was not independently associated with survival [80]. However the time to transfusion of plasma vs RBC was significantly longer 15 vs 90 min, confounding their conclusions.

The preponderance of the current literature, but not all, indicates patients in severe hemorrhagic shock may benefit from increased ratios of plasma and platelets to RBCs [81,82]. Conversely, DCR should not be performed in patients who are not in hemorrhagic shock or who are not at high risk of massive transfusion, as the increased plasma and platelets will likely increase multiple organ failure, with no increased survival benefit. The American Association of Blood Banks (AABB) has recently performed an evidenced based review for the $\mathrm{AABB}$ plasma guideline project and has concluded that massive transfusion appears to be one situation where giving increased amounts of plasma prevents death. 


\subsection{Risk vs benefits}

As the use of plasma and platelet transfusion increases, the risks associated with these products must be clearly understood, and placed within the framework of their potential benefit. Plasma transfusion has been associated with increased risk of allergic reactions, transfusion associated acute lung injury (TRALI), transfusion associated cardiac overload (TACO), and acute respiratory distress syndrome (ARDS) [83,84]. Platelet transfusion has been associated with each of these and in addition bacterial contamination, deep venous thromboembolism (DVT), and febrile reactions [85]. The risks of these adverse events have not been well quantified with a wide range of reported occurrences. The reported incidence of TRALI ranges from 1/500 to 1/5000 to 1/60,000 for platelets, all blood components, and fresh frozen plasma transfusion, respectively $[84,85]$. In patients without severe bleeding this risk profile outweighs any potential benefit. However, for patients with severe traumatic injury and hemorrhagic shock the apparent survival benefit with increased plasma and platelet transfusion likely far exceeds the uncommon to rare risks of transfusion reactions, TRALI, TACO, and infections that can be associated with their use. The risks associated with increased plasma and platelet use must also be put into perspective with the increased risk of thrombosis, sepsis, organ failure and death associated with RBC transfusion, which have been recently reviewed [86-89]. Unfortunately, there are no prospective studies that evaluated the clinical benefit vs the risks associated with transfusion of these products.

\subsection{Whole blood}

While whole blood is an AABB approved product its use is a controversial subject, often eliciting fairly emotional responses. Unfortunately, little data are available describing outcomes of trauma patients transfused either components or whole blood. What data are available largely come from military conflicts, where follow-up data can be difficult. The US Military has transfused $>6000$ units of FWB over the last 8 years and their published data suggests that use of FWB is superior to component therapy [35-41]. The risks of transmitted disease must be considered vs the benefit of rapid replacement of fresh products in a group of patients that have an extremely high mortality (20-50\%) [38]. Finally what exactly constitutes fresh whole blood vs whole blood is unclear as the definitions range from 24 to $72 \mathrm{~h}$ after donation and include various storage temperature variables [18]. These questions will remain until prospective randomized studies are performed. Interestingly, it is in the developing world, where whole blood is still routinely utilized, where large randomized studies might provide much of these randomized data. The balance between inventory management, safety from blood borne pathogens and optimal clinical outcome must be pursued.

\subsection{Future studies}

Many centers have published their retrospective data describing increased plasma and platelet ratios on outcome. We have recently started enrolling transfused trauma patients into a prospective observational study of massive transfusion trial (PROMTT). This 10 center study will record minute by minute what resuscitation products are transfused in what order, and the patient's complications and outcomes. These data can then be used to design a prospective randomized trial of high vs low ratios. For the first time, we will have Level 1 data guiding transfusion therapy in severely injured and massively injured trauma patients.

\section{Conclusion}

Trauma is the most common cause of death for patients 1-40 years of age, death from hemorrhagic shock is the most common cause of preventable death within $6 \mathrm{~h}$ of admission. These patients are frequently coagulopathic upon admission, and the rapid identification and treatment of traumatic coagulopathy may improve survival. Therefore, it is imperative that 
we better understand the pathophysiology of traumatic coagulopathy and ACoTS, and develop methods to decrease death from hemorrhage. We must also continue to develop research protocols to determine the optimal transfusion approach for patients with traumatic shock. Current data indicates that the early identification of coagulopathy and its treatment with RBCs, plasma, and platelets in a 1:1:1 unit ratio achieved with the use of fresh RBCs, thawed plasma, and platelets, limited use of crystalloids, and possibly with the early and appropriate use of whole blood may improve survival in uncommon patient who presents with severe traumatic injury and life-threatening bleeding. In addition to optimal resuscitation rapid surgical control of the source of bleeding with prevention or treatment of acidosis, hypothermia and hypocalcemia is essential. These principles of DCR should only be applied for patients with life-threatening bleeding with hemorrhagic shock and should not be overused. Accurate predictive models that can be performed upon admission may be able to identify the patients who will benefit from hemostatic resuscitation, thus optimizing benefit and minimizing risk [90-93]. This is an area of active research and is likely the most important current effort. The US Department of Defense has funded a prospective observational transfusion trial at 10 busy trauma centers, and these data will start to answer many of the questions raised in this review. Future prospective randomized studies are required to definitively answer what resuscitation approach in the massively bleeding patient best balances benefit and risk.

\section{References}

[1]. Trauma Facts. 2008. Accessed at, http://www.aast.org/TraumaFacts/dynamic.aspx ?id=964

[2]. CDC. Deaths: final data for 2004. US Department of Health and Human Services. CDC, National Center for Health Statistics; 2007.

[3]. Lopez AD, Mathers CD, Ezzati M, Jamison DT, Murray CJ. Global and regional burden of disease and risk factors, 2001: systematic analysis of population health data. Lancet. May 27; 2006 367(9524):1747-57. [PubMed: 16731270]

[4]. Esposito TJ, Sanddal ND, Hansen JD, Reynolds S. Analysis of preventable trauma deaths and inappropriate trauma care in a rural state. J Trauma. 1995; 39:955-62. [PubMed: 7474014]

[5]. Esposito TJ, Sanddal TL, Reynolds SA, Sanddal ND. Effect of a voluntary trauma system on preventable death and inappropriate care in a rural state. J Trauma. 2003; 54:663-70. [PubMed: 12707527]

[6]. Tien HC, Spencer F, Tremblay LN, Rizoli SB, Brenneman FD. Preventable deaths from hemorrhage at a level I Canadian trauma center. J Trauma. 2007; 62:142-6. [PubMed: 17215745]

[7]. Demetriades D, Murray J, Charalambides K, et al. Trauma fatalities: time and location of hospital deaths. J Am Coll Surg. 2004; 198:20-6. [PubMed: 14698307]

[8]. Peng R, Chang C, Gilmore D, Bongard F. Epidemiology of immediate and early trauma deaths at an urban Level I trauma center. Am Surg. 1998; 64:950-4. [PubMed: 9764699]

[9]. Sauaia A, Moore FA, Moore EE, et al. Epidemiology of trauma deaths: a reassessment. J Trauma. 1995; 38:185-93. [PubMed: 7869433]

[10]. Teixeira PG, Inaba K, Hadjizacharia P, et al. Preventable or potentially preventable mortality at a mature trauma center. J Trauma. Dec; 2007 63(6):1338-47. [PubMed: 18212658]

[11]. Acosta JA, Yang JC, Winchell RJ, et al. Lethal injuries and time to death in a level I trauma center. J Am Coll Surg. May; 1998 186(5):528-33. [PubMed: 9583692]

[12]. Gruen RL, Jurkovich GJ, McIntyre LK, Foy HM, Maier RV. Patterns of errors contributing to trauma mortality: lessons learned from 2,594 deaths. Ann Surg. Sep; 2006 244(3):371-80. [PubMed: 16926563]

[13]. Demetriades D, Kimbrell B, Salim A, et al. Trauma deaths in a mature urban trauma system: is "trimodal" distribution a valid concept? J Am Coll Surg. Sep; 2005 201(3):343-8. [PubMed: 16125066]

[14]. Peng R, Chang C, Gilmore D, Bongard F. Epidemiology of immediate and early trauma deaths at an urban Level I trauma center. Am Surg. Oct; 1998 64(10):950-4. [PubMed: 9764699] 
[15]. Moore FA, Nelson T, McKinley BA, et al. StO2 Study Group. Massive transfusion in trauma patients: tissue hemoglobin oxygen saturation predicts poor outcome. J Trauma. Apr; 2008 64(4): 1010-23. [PubMed: 18404069]

[16]. Hess JR. Blood and coagulation support in trauma care. Hematology Am Soc Hematol Educ Program. 2007:187-91. [PubMed: 18024628]

[17]. Como JJ, Dutton RP, Scalea TM, Edelman BB, Hess JR. Blood transfusion rates in the care of acute trauma. Transfusion. Jun; 2004 44(6):809-13. [PubMed: 15157244]

[18]. Hughes JD, Macdonald VW, Hess JR. Warm storage of whole blood for 72 hours. Transfusion. Nov; 2007 47(11):2050-6. [PubMed: 17958534]

[19]. Hess JR, Brohi K, Dutton RP, et al. The coagulopathy of trauma: a review of mechanisms. J Trauma. 2008; 65:748-54. [PubMed: 18849786]

[20]. Brohi K, Cohen MJ, Ganter MT, et al. Acute coagulopathy of trauma: hypoperfusion induces systemic anticoagulation and hyperfibrinolysis. J Trauma. 2008; 64:1211-7. [PubMed: 18469643]

[21]. Hoyt DB, Dutton RP, Hauser CJ, et al. Management of coagulopathy in the patients with multiple injuries: results from an international survey of clinical practice. J Trauma. 2008; 65:755-65. [PubMed: 18849787]

[22]. Brohi K, Singh J, Heron M, Coats T. Acute traumatic coagulopathy. J Trauma. 2003; 54:112730. [PubMed: 12813333]

[23]. MacLeod JB, Lynn M, McKenney MG, Cohn SM, Murtha M. Early coagulopathy predicts mortality in trauma. J Trauma. 2003; 55:39-44. [PubMed: 12855879]

[24]. Holcomb JB, Wade CE, Michalek JE, et al. Increased plasma and platelet to red blood cell ratios improves outcome in 466 massively transfused civilian trauma patients. Ann Surg. Sep; 2008 248(3):447-58. [PubMed: 18791365]

[25]. Zink KA, Sambasivan CN, Holcomb JB, Chisholm G, Schreiber MA. A high ratio of plasma and platelets to packed red blood cells in the first 6 hours of massive transfusion improves outcomes in a large multicenter study. Am J Surg. May; 2009 197(5):565-70. [PubMed: 19393349]

[26]. Spinella PC, Perkins JG, Grathwohl KW, et al. Effect of plasma and red blood cell transfusions on survival in patients with combat related traumatic injuries. J Trauma. 2008; 64:S69-78. [PubMed: 18376175]

[27]. Hess JR, Dutton RB, Holcomb JB, Scalea TM. Giving plasma at a 1:1 ratio with red cells in resuscitation: who might benefit? Transfusion. 2008; 48:1763-5. [PubMed: 18482190]

[28]. Hess JR, Thomas MJ. Blood use in war and disaster: lessons from the past century. Transfusion. 2003; 43:1622-33. [PubMed: 14617324]

[29]. Starr, D. Blood. Harper Collins; New York: 2002.

[30]. Hess JR. An update on solutions for red cell storage. Vox Sang. Jul; 2006 91(1):13-9. [PubMed: 16756596]

[31]. Zimrin AB, Hess JR. Current issues relating to the transfusion of stored red blood cells. Vox Sang. Feb; 2009 96(2):93-103. [PubMed: 19152602]

[32]. Como JJ, Dutton RP, Scalea TM, Edelman BB, Hess JR. Blood transfusion rates in the care of acute trauma. Transfusion. 2004; 44:809-13. [PubMed: 15157244]

[33]. Ho AM, Karmakar MK, Dion PW. Are we giving enough coagulation factors during major trauma resuscitation? Am J Surg. 2005; 190:479-84. [PubMed: 16105540]

[34]. Practice Guidelines for blood component therapy. A report by the American Society of Anesthesiologists Task Force on Blood Component Therapy. Anesthesiology. 1996; 84:732-47. [PubMed: 8659805]

[35]. Mabry RL, Holcomb JB, Baker AM, et al. United States Army Rangers in Somalia: an analysis of combat casualties on an urban battlefield. J Trauma. Sep; 2000 49(3):515-29. [PubMed: 11003332]

[36]. Kauvar DS, Holcomb JB, Norris GC, Hess JR. Fresh whole blood transfusion: a controversial military practice. J Trauma. Jul; 2006 61(1):181-4. [PubMed: 16832268]

[37]. Repine TB, Perkins JG, Kauvar DS, Blackborne L. The use of fresh whole blood in massive transfusion. J Trauma. 2006; 60:S59-69. [PubMed: 16763483] 
[38]. Spinella PC, Perkins JP, Grathwohl KG, et al. The risks associated with fresh whole blood and RBC transfusions in a combat support hospital. Crit Care Med. 2007; 35:2576-81. [PubMed: 17828033]

[39]. Spinella PC, Perkins JG, Grathwohl KW, Beekley AC, Holcomb JB. Warm fresh whole blood is independently associated with improved survival for patients with combat-related traumatic injuries. J Trauma. Apr; 2009 66(4 Suppl):S69-76. [PubMed: 19359973]

[40]. Spinella PC. Warm fresh whole blood transfusion for severe hemorrhage: U.S. military and potential civilian applications. Crit Care Med. Jul; 2008 36(7 Suppl):S340-5. [PubMed: 18594261]

[41]. Spinella PC, Perkins JG, Grathwohl KW, et al. 31st CSH Research Working Group. Fresh whole blood transfusions in coalition military, foreign national, and enemy combatant patients during Operation Iraqi Freedom at a U.S. combat support hospital. World J Surg. Jan; 2008 32(1):2-6. [PubMed: 17990028]

[42]. Cannon WB. The preventive treatment of wound shock. JAMA. 1918; 70:618.

[43]. Beecher HK. Preparation of battle casualties for surgery. Ann Surg. 1945; 121:769-92. [PubMed: 17858614]

[44]. Holcomb JB. Fluid resuscitation in modern combat casualty care: lessons learned from Somalia. J Trauma. 2003; 54:S46-51. [PubMed: 12768103]

[45]. McMullin, NR.; Holcomb, JB.; Sondeen, J. Hemostatic resuscitation. In: Vincent, J., editor. Yearbook of intensive care and emergency medicine. Springer; New York: 2006. p. 265-78.

[46]. Hess JR, Holcomb JB, Hoyt DB. Damage control resuscitation: the need for specific blood products to treat the coagulopathy of trauma. Transfusion. 2006; 46:685-6. [PubMed: 16686833]

[47]. Holcomb JB, Jenkins D, Rhee P, et al. Damage control resuscitation: directly addressing the early coagulopathy of trauma. J Trauma. 2007; 62:307-10. [PubMed: 17297317]

[48]. Borgman MA, Spinella PC, Perkins JG, et al. The ratio of blood products transfused affects mortality in patients receiving massive transfusions at a combat support hospital. J Trauma. 2007; 63:805-13. [PubMed: 18090009]

[49]. Beekley AC. Damage control resuscitation: a sensible approach to the exsanguinating surgical patient. Crit Care Med. 2008; 36:S267-74. [PubMed: 18594252]

[50]. Sondeen JL, Coppes VG, Holcomb JB. Blood pressure at which rebleeding occurs after resuscitation in swine with aortic injury. J Trauma. 2003; 54:S110-7. [PubMed: 12768112]

[51]. Bickell WH, Wall MJ Jr, Pepe PE, et al. Immediate versus delayed fluid resuscitation for hypotensive patients with penetrating torso injuries. N Engl J Med. 1994; 331:1105-9. [PubMed: 7935634]

[52]. Maegele M, Lefering R, Paffrath T, Tjardes T, Simanski C, Bouillon B. Red blood cell to plasma ratios transfused during massive transfusion are associated with mortality in severe multiply injury: a retrospective analysis from the Trauma Registry of the Deutsche Gesellschaft fur Unfallchirurgie. Vox Sang. 2008; 95:112-9. [PubMed: 18557827]

[53]. Gunter OL Jr, Au BK, Isbell JM, Mowery NT, Young PP, Cotton BA. Optimizing outcomes in damage control resuscitation: identifying blood product ratios associated with improved survival. J Trauma. 2008; 65:527-34. [PubMed: 18784564]

[54]. Duchesne JC, Hunt JP, Wahl G, et al. Review of current blood transfusions strategies in a mature level I trauma center: were we wrong for the last 60 years? J Trauma. 2008; 65:272-8. [PubMed: 18695461]

[55]. Sperry JL, Ochoa JB, Gunn SR, et al. An FFP: PRBC transfusion ratio $>/=1: 1.5$ is associated with a lower risk of mortality after massive transfusion. J Trauma. 2008; 65:986-93. [PubMed: 19001962]

[56]. Malone DL, Hess JR, Fingerhut A. Massive transfusion practices around the globe and a suggestion for a common massive transfusion protocol. J Trauma. 2006; 60:S91-6. [PubMed: 16763487]

[57]. Stinger HK, Spinella PC, Perkins JG, et al. The ratio of fibrinogen to red cells transfused affects survival in casualties receiving massive transfusions at an army combat support hospital. J Trauma. 2008; 64:S79-85. [PubMed: 18376176] 
[58]. Cotton BA, Au BK, Nunez TC, Gunter OL, Robertson AM, Young PP. Predefined massive transfusion protocols are associated with a reduction in organ failure and postinjury complications. J Trauma. 2009; 66:41-9. [PubMed: 19131804]

[59]. Dente CJ, Shaz BH, Nicholas JM, et al. Improvements in early mortality and coagulopathy are sustained better in patients with blunt trauma after institution of a massive transfusion protocol in a civilian level I trauma center. J Trauma. 2009; 66:1616-24. [PubMed: 19509623]

[60]. Watson GA, Sperry JL, Rosengart MR, et al. Inflammation and Host Response to Injury Investigators. Fresh frozen plasma is independently associated with a higher risk of multiple organ failure and acute respiratory distress syndrome. J Trauma. Aug; 2009 67(2):221-30. [PubMed: 19667872]

[61]. Cotton BA, Gunter OL, Isbell J, et al. Damage control hematology: the impact of a trauma exsanguination protocol on survival and blood product utilization. J Trauma. 2008; 64:1177-83. [PubMed: 18469638]

[62]. Cosgriff N, Moore EE, Sauaia A, Kenny-Moynihan M, Burch JM, Galloway B. Predicting lifethreatening coagulopathy in the massively transfused trauma patient: hypothermia and acidoses revisited. J Trauma. 1997; 42:857-62. [PubMed: 9191667]

[63]. Cinat ME, Wallace WC, Nastanski F, et al. Improved survival following massive transfusion in patients who have undergone trauma. Arch Surg. 1999; 134:964-70. [PubMed: 10487591]

[64]. Gonzalez EA, Moore FA, Holcomb JB, et al. Fresh frozen plasma should be given earlier to patients requiring massive transfusion. J Trauma. 2007; 62:112-9. [PubMed: 17215741]

[65]. Teixeira PG, Inaba K, Shulman I, et al. Impact of plasma transfusion in massively transfused trauma patients. J Trauma. 2009; 66:693-7. [PubMed: 19276739]

[66]. Harrigan C, Lucas CE, Ledgerwood AM, Walz DA, Mammen EF. Serial changes in primary hemostasis after massive transfusion. Surgery. 1985; 98:836-44. [PubMed: 4049256]

[67]. Counts RB, Haisch C, Simon TL, Maxwell NG, Heimbach DM, Carrico CJ. Hemostasis in massively transfused trauma patients. Ann Surg. Jul; 1979 190(1):91-9. [PubMed: 464685]

[68]. Carrico CJ, Canizaro PC, Shires GT. Fluid resuscitation following injury: rationale for the use of balanced salt solutions. Crit Care Med. Mar-Apr; 1976 4(2):46-54. [PubMed: 819213]

[69]. Johansson PI, Stensballe J, Rosenberg I, Hilslov TL, Jorgensen L, Secher NH. Proactive administration of platelets and plasma for patients with a ruptured abdominal aortic aneurysm: evaluating a change in transfusion practice. Transfusion. 2007; 47:593-8. [PubMed: 17381616]

[70]. Gruenwald CE, McCrindle BW, Crawford-Lean L, et al. Reconstituted fresh whole blood improves clinical outcomes compared with stored component blood therapy for neonates undergoing cardiopulmonary bypass for cardiac surgery: a randomized controlled trial. J Thorac Cardiovasc Surg. Dec; 2008 136(6):1442-9. [PubMed: 19114187]

[71]. Alexander JM, Sarode R, McIntire DD, Burner JD, Leveno KJ. Whole blood in the management of hypovolemia due to obstetric hemorrhage. Obstet Gynecol. Jun; 2009 113(6):1320-6. [PubMed: 19461429]

[72]. Moore FD, Shires GT. Moderation. Anesth Analg. 1968; 47:506-8. [PubMed: 5691690]

[73]. Cotton BA, Guy JS, Morris JA Jr, Abumrad NN. The cellular, metabolic, and systemic consequences of aggressive fluid resuscitation strategies. Shock. 2006; 26:115-21. [PubMed: 16878017]

[74]. Balogh Z, McKinley BA, Holcomb JB, et al. Both primary and secondary abdominal compartment syndrome can be predicted early and are harbingers of multiple organ failure. $\mathrm{J}$ Trauma. 2003; 54:848-61. [PubMed: 12777898]

[75]. Brandstrup B, Tonnesen H, Beier-Holgersen R, et al. Effects of intravenous fluid restriction on postoperative complications: comparison of two perioperative fluid regimens: a randomized assessor-blinded multicenter trial. Ann Surg. 2003; 238:641-8. [PubMed: 14578723]

[76]. Wiedemann HP, Wheeler AP, Bernard GR, et al. Comparison of two fluid-management strategies in acute lung injury. N Engl J Med. 2006; 354:2564-75. [PubMed: 16714767]

[77]. Pati S, Matijevic N, Doursout MF, et al. The protective effects of day 0 fresh frozen plasma (FFP) on vascular endothelial permeability, coagulation, and resuscitation after hemorrhagic shock are time dependent and diminish between day 0 and day 5. Accepted J Trauma. 2009 
[78]. Reed RL 2nd, Ciavarella D, Heimbach DM, et al. Prophylactic platelet administration during massive transfusion. A prospective, randomized, double-blind clinical study. Ann Surg. 1986; 203:40-8. [PubMed: 3510591]

[79]. Faringer PD, Mullins RJ, Johnson RL, Trunkey DD. Blood component supplementation during massive transfusion of AS-1 red cells in trauma patients. J Trauma. Apr; 1993 34(4):481-7. [PubMed: 8487331]

[80]. Snyder CW, Weinberg JA, McGwin G Jr, et al. The relationship of blood product ratio to mortality: survival benefit or survival bias? J Trauma. 2009; 66:358-64. [PubMed: 19204508]

[81]. Kashuk JL, Moore EE, Johnson JL, et al. Postinjury life threatening coagulopathy: is 1:1 fresh frozen plasma: packed red blood cells the answer? J Trauma. 2008; 65:261-71. [PubMed: 18695460]

[82]. Scalea TM, Bochicchio KM, Lumpkins K, et al. Early aggressive use of fresh frozen plasma does not improve outcome in critically injured trauma patients. Ann Surg. 2008; 248:578-84. [PubMed: 18936570]

[83]. Gajic O, Dzik WH, Toy P. Fresh frozen plasma and platelet transfusion for nonbleeding patients in the intensive care unit: benefit or harm? Crit Care Med. 2006; 34:S170-3. [PubMed: 16617262]

[84]. Silliman CC, Ambruso DR, Boshkov LK. Transfusion-related acute lung injury. Blood. 2005; 105:2266-73. [PubMed: 15572582]

[85]. MacLennan S, Williamson LM. Risks of fresh frozen plasma and platelets. J Trauma. 2006; 60:S46-50. [PubMed: 16763481]

[86]. Napolitano LM, Corwin HL. Efficacy of red blood cell transfusion in the critically ill. Crit Care Clin. 2004; 20:255-68. [PubMed: 15135464]

[87]. Lamboo M, Poland DC, Eikenboom JC, et al. Coagulation parameters of thawed fresh-frozen plasma during storage at different temperatures. Transfus Med. 2007; 17:182-6. [PubMed: 17561859]

[88]. Weinberg JA, McGwin G Jr, Griffin RL, et al. Age of transfused blood: an independent predictor of mortality despite universal leukoreduction. J Trauma. 2008; 65:279-84. [PubMed: 18695462]

[89]. Zallen G, Offner PJ, Moore EE, et al. Age of transfused blood is an independent risk factor for postinjury multiple organ failure. Am J Surg. 1999; 178:570-2. [PubMed: 10670874]

[90]. Yucel N, Lefering R, Maegele M, et al. Trauma Associated Severe Hemorrhage (TASH)-Score: probability of mass transfusion as surrogate for life threatening hemorrhage after multiple trauma. J Trauma. 2006; 60:1228-37. [PubMed: 16766965]

[91]. Nunez TC, Voskresensky IV, Dossett LA, Shinall R, Dutton WD, Cotton BA. Early prediction of massive transfusion in trauma: simple as $\mathrm{ABC}$ (assessment of blood consumption)? J Trauma. 2009; 66:346-52. [PubMed: 19204506]

[92]. Schreiber MA, Perkins J, Kiraly L, Underwood S, Wade C, Holcomb JB. Early predictors of massive transfusion in combat casualties. J Am Coll Surg. 2007; 205:541-5. [PubMed: 17903727]

[93]. McLaughlin DF, Niles SE, Salinas J, et al. A predictive model for massive transfusion in combat casualty patients. J Trauma. Feb; 2008 64(2 Suppl):S57-63. [PubMed: 18376173] 